\title{
Osäkerhetens politik i praktiken: Presidentvalet 2020 som förändrade Belarus
}

\author{
Sofie Bedford* \\ IRES Institutet för Ryssland och Eurasienstudier, Uppsala universitet, Sverige
}

\begin{abstract}
The Politics of Uncertainty' in Practice: The 2020 Presidential Election that Changed Belarus

Up until 2020 Aleksandr Lukashenka's authoritarian regime had ruled Belarus for 26 years without major challenges. Thus, the popular mobilization that took shape in connection with the August 2020 presidential election came as a surprise. It was not the first time that elections in Belarus were not fair - but it was the first time that large sectors of the population reacted openly. Six months later, Belarusians all over the country were still contesting the falsified results. What contributed to this mobilization and politicization of a previously largely apolitical society? Why does that development represent such a serious threat to the authoritarian system? This study sees the Belarusian presidential election and its aftermath as illustrating the 'politics of uncertainty' of electoral authoritarian regimes. Because of the intrinsic insecurity of authoritarian systems, all regular elections in that context entail risks, which in theory might lead to change. In Belarus, the emergence of latent threats to the regime's legitimacy in the form of social cleavages and an economic crisis, combined with the fundamental dynamics of the 'election game', amplified this instability. The election served as the starting point for a process of transformation that became the most serious threat ever faced by the Lukashenka regime.
\end{abstract}

Keywords: Belarus, politics of uncertainty, mobilization, electoral authoritarianism, political apathy

När de belarusiska ledarna beslöt att inte skjuta upp presidentvalet i augusti 2020, trots att det varit fullt möjligt med hänvisning till den pågående globala coronapandemin, gjorde de ett ödesdigert misstag. De förväntade sig att Aleksandr Lukasjenka i vanlig ordning, utan större komplikationer, skulle bli omvald för femte gången. De tog fel. Det är inte första gången valresultaten i Belarus förfalskats. Faktum är att inget av valen sedan 1994, då Lukasjenka kom till makten, har bedömts som fria och rättvisa enligt internationella normer. Det är heller inte första gången som valresultaten öppet

\footnotetext{
^Kontaktinformasjon: Sofie Bedford, e-post: sofie.bedford@ires.uu.se 
ifrågasätts. Demonstrationerna mot valfusket i presidentvalet 2006 samlade över 10 000 personer, den största protesten mot regimen på många år. Inspirerade av den orangea revolutionen i Ukraina upprättade aktivisterna ett tältläger på Oktobertorget i Minsk som överlevde i fem dagar innan det slutligen brutalt revs av polisen. Minst 500 personer greps för att ha deltagit i olaglig verksamhet (Naumov, 2014). Efter Lukasjenkas fjärde omval 2010 lyckades oppositionskandidaterna åter samla tusentals människor för att protestera mot de officiella resultaten, men även den här gången slutade det i tragedi. Protesterna splittrades ännu mer brutalt och hundratals arresterades, inklusive sju av de nio presidentkandidaterna (Ash, 2015; Padhol \& Marples, 2011).

Den proteströrelse som växte fram i samband med valet 2020 är ett väldigt annorlunda fenomen än de demonstrationer som ägt rum efter tidigare val. Inte bara var dessa mycket mindre i omfattning, den största skillnaden består i att tidigare protester framförallt drevs av den "traditionella» oppositionen, det vill säga de enda som konstant krävde politisk förändring. Dagens protester karaktäriseras i stället av att många, eller rentav de flesta, av dem som nu är ute på gatorna och öppet utmanar systemet inte tidigare engagerat sig politiskt. ${ }^{1}$ Det är likaså signifikant att de protesterar för att de röstade på Svjatlana Tsichanouskaja. Så många som 200000 personer rapporteras ha slutit upp på Stella-torget i Minsk en vecka efter valet för att opponera sig mot valresultatet och protestera mot president Lukasjenkas styre och den autokratiska regim han representerar. Trots den våldsamma reaktionen från myndigheterna fortsätter en stor del av befolkningen ett halvår senare att gå ut på gatorna och öppet ge uttryck för sin önskan om förändring.

Efter våldsamheterna som mötte demonstranterna 2006 och 2010 var det få som förväntade sig att en resning av den här kalibern var möjlig i Belarus. Syftet med den här artikeln är dels att bringa klarhet i vilka omständigheter som bidrog till en sådan oväntad och spektakulär mobilisering och politisering av det belarusiska samhället, och dels att förklara varför denna utveckling är så allvarlig för den auktoritära regimen. För att göra detta tar artikeln sin teoretiska utgångspunkt i litteraturen om elektoral autokrati.

\section{Elektoral autokrati och osäkerhetens politik}

Trots att utvecklingen i Belarus kom som en överraskning för de flesta är den akademiska litteraturen om så kallade elektorala autokratier ett ypperligt teoretiskt verktyg för att $\mathrm{i}$ efterhand bättre försöka förstå vad som hände och varför. Presidentvalet 2020 och dess efterdyningar illustrerar på ett bra sätt det Schedler (2013) kallat "osäkerhetens politik" (politics of uncertainty).

Elektorala autokratier är regimer som håller lagbundna val till styrande organ som verkar demokratiska, men eftersom de saknar de grundläggande fri- och

\footnotetext{
${ }^{1}$ Enligt en undersökning i december 2020 sade sig endast fyra procent av de tillfrågade ha deltagit i protester innan 2020 (Krawatzek \& Sasse, 2020).
} 
rättigheter som försäkrar att det faktiskt finns valmöjligheter saknar dessa i praktiken betydelse (Hadenius \& Teorell, 2007; Schedler, 2013). I en "hegemonisk» elektoral autokrati som Belarus karaktäriseras regimen av att den styrande eliten har monopol på den politiska makten, ${ }^{2}$ men till skillnad mot en »diktatur» är formella val en viktig del av den demokratiska fasaden (Lindberg \& Teorell, 2013). ${ }^{3}$ Därför är val i elektorala autokratier generellt minimalt inkluderande (allmän rösträtt), minimalt pluralistiska (oppositionspartier tillåts delta, men det är till exempel svårt att registrera nya partier), minimalt konkurrenskraftiga (partier och kandidater utanför det ledande skiktet tillåts vinna röster och mandat, men inte vinna valet) och minimalt öppna (oliktänkande är inte föremål för massivt, men ofta selektivt och sporadiskt förtryck) (Schedler, 2006). Eftersom de nuvarande ledarna kontrollerar och dominerar hela valprocessen så blir det officiella resultatet nästan alltid det "rätta».

Trots detta är valsituationen inte helt statisk. För dem som vill se politisk förändring blir valen, trots att de ofta är uppgjorda på förhand, viktiga eftersom valrörelsen egentligen är det enda tillfälle då oppositionspolitiker i en auktoritär stat får tillgång till det offentliga rummet. Oavsett hur mycket de auktoritära ledarna än försöker kontrollera omständigheterna så kan de aldrig vara helt säkra på att de verkligen lyckats identifiera och eliminera alla hot mot sin maktposition. Oppositionella aktörer strävar ständigt efter att förstärka och utnyttja osäkerheten, vilket i slutändan gör att alla regelbundna val medför vissa risker för regimen, vilka i teorin kan leda till förändring. Detta har visat sig inte minst i samband med de olika färgstarka, blomdoftande demokratiska folkresningarna i olika postkommunistiska länder under tidigt 2000-tal som Bunce och Wolchik (2006) benämnt "elektorala revolutioner $\rangle^{4}$ (men som ofta också refereras till som "färgrevolutioner»). Det dessa har gemensamt är att »ett val kom att bli den politiska vändpunkten som ledde till ett nederlag för illiberala politiska krafter och en seger för den liberala oppositionen» (Bunce \& Wolchik, 2006, s. 5). Även om den folkliga resningen i Belarus ännu inte lett till "framgång», så som den definieras i deras forskning så kan den inte desto mindre liknas vid en elektoral revolution.

Liksom i andra autokratier brukade valen i Belarus egentligen inte betyda någonting. Regimen kontrollerar valprocessen från början till slut - de bestämmer vem som kan delta och kontrollerar förloppet och utfallet. Alla vet vem som kommer att vinna. Den här gången fanns emellertid särskilda förhållanden som bidrog till att aktivera och intensifiera osäkerhetsmomentet i valsituationen. För det första kom den auktoritära regimens legitimitet att bli kraftigt ifrågasatt till följd av att två allvarliga problem som varit mer eller mindre dolda kom upp till ytan. Frustrationen över

\footnotetext{
${ }^{2}$ Till skillnad från i så kallat konkurrensutsatta autokratier (competetive autocracies), vars val kännetecknas av ett visst mått av genuin tävlan mellan den sittande regimen och dess utmanare.

3 Enligt till exempel Schedler (2013) är den elektorala autokratin numera den allra vanligaste formen av icke-demokrati.

${ }^{4}$ På engelska är uttrycket electoral revolution. Varianten valrevolution förekommer ibland på svenska, men jag föredrar elektoral revolution.
} 
landets långvariga ekonomiska kris kulminerade i samband med covid-19-krisen, samtidigt som den klyfta i samhället som växt fram mellan det system Lukasjenka representerar och den del av befolkningen som vill se förändring ställdes på sin spets. För det andra så förändrades dynamiken i det belarusiska "valspelet» när befolkningens roll i valprocessen förändrades.

\section{Bakgrund: Politiken som försvann}

Att driva med president Lukasjenka som lett landet i 26 år är både vanligt och mycket populärt i Belarus. Ofta gör skämten inte bara narr av presidentens långa regeringstid, utan också det politiska systemet i allmänhet och valen i synnerhet. Även Lidzija Jarmosjyna, ordförande för centrala valnämnden i Belarus sedan 1996, som misstänks för att ligga bakom ett stort antal valbedrägerier (och därför till exempel har beskrivits som en "valtrollkarl», se Astapova, 2017) får sig ofta en släng av sleven vilket syns i exemplet nedan:

Chefen för den centrala valnämnden i Belarus, Lidzija Jarmosjyna, säger till president Lukasjenka:

- Aleksandr Grigorievitj, jag har två nyheter: en god och en dålig. Vilken ska jag börja med?

- Den goda.

- Du har blivit vald till president.

- Okej, vad är den dåliga?

- Ingen röstade på dig.

I all sin banalitet kan den här typen av anekdoter sägas illustrera ett häpnadsväckande fenomen: valfusk ses som vardagsmat och trots att majoriteten av befolkningen är väl medveten om bristen på reell demokrati i sitt land tycks de helt enkelt acceptera att den politiska situationen är oföränderlig. Enligt Gel'man (2010) bidrar en sådan "resignerad acceptans» ofrånkomligen till den auktoritära regimens fortlevnad. Skämtet ovan understryker dock att anledningen till att det auktoritära systemet i Belarus varit så seglivat inte är att befolkningen nödvändigtvis är särskilt lojal mot regimen. Snarare var orsaken att myndigheterna framgångsrikt skuffat undan politiken från det offentliga rummet. Eller mer specifikt, att de lyckades göra politik till en icke-fråga bland en stor del av befolkningen. Eftersom folk i allmänhet upplevde att politik var ointressant och irrelevant så tyckte de heller inte att frågan om regeringsskifte spelade någon större roll. Tack vare detta säkrades det auktoritära systemets fortsatta existens (Bedford, 2017).

\section{En politisk opposition utan relevans och inflytande $i$ politiken}

Hur kunde politiken "försvinna»? Ett viktigt skäl var den totala marginaliseringen av oppositionen. Charnysh och Kulakevich (2016) konstaterar cyniskt att det faktum 
att det totalt finns femton partier ger intrycket att det finns politisk konkurrens i Belarus, vilket gör det möjligt för Lukasjenkas regering att motverka västerländsk kritik. Partierna är dock i princip isolerade från det belarusiska samhället och spelar en högst begränsad roll i politiken. Inget parti har haft regeringsmakten eller någonsin mer än symbolisk representation i parlamentet sedan Lukasjenkas tillträde 1994 (Minchenia, 2020). Även om det på pappret finns ideologiska skillnader mellan partierna är den stora skiljelinjen inställningen till Lukasjenkas regim. De som är emot den beskrivs som oppositionspartier. ${ }^{5}$ Dessa verkar under mer eller mindre konstant förtryck medan den andra gruppen, det vill säga de som stödjer Lukasjenka, åtnjuter viss grad av stöd och beskydd.

Genom sin totala kontroll över hela den statliga administrationen, ekonomin och media så har de nuvarande ledarna lätt kunnat reglera vem som kan säga vad och var - de har under åren effektivt säkerställt att oppositionella aktörer inte fick tillgång till lagliga kanaler eller plattformar där makthavarna kunde utmanas. Oppositionspartierna hade i slutändan således få eller ofta inga möjligheter att vara politiska aktörer i realiteten. Den enda gång de ges tillåtelse att »agitera» bland folket är just under valkampanjerna.

Även om den elektorala autokratiska regimen officiellt framhåller att valen är en manifestation av folkviljan så var det uppenbart i Belarus att varken staten eller samhället i praktiken tog dem på allvar. Valen sågs som ett slags "spel» där oppositionella aktörer tilläts delta, men deras medverkan bara var symbolisk. Genom att delta i detta "valspel» så kom de oppositionella aktörerna också att ses som »skådespelare». Konsekvensen var att oppositionen upplevdes som symbolisk snarare än relevant av befolkningen i stort, vilket bidrog till dess negativa rykte. Samtidigt går det att utläsa i kritiken mot oppositionen att många i befolkningen är besvikna över att oppositionen inte lyckats »leverera» politisk förändring varken genom val eller elektoral revolution (Bedford, 2017).

\section{Ett folk som inte ville »vakna»}

En annan viktig aspekt är det faktum att den politiska oppositionens kamp mot den auktoritära regimen kommit att bli så nära förbunden med kampen om den belarusiska identiteten. Bekus (2010, s. 282) förklarar att eftersom de belarusiska oppositionsledarna såg »det nationella uppvaknandet som den viktigaste förutsättningen för demokratisering av landet» blev deras "retorik om nationell väckelse i den belarusiska offentliga sfären» »ett viktigt instrument för att locka människor mot kampen mot auktoritärism». Hon beskriver en situation där två konkurrerande myter om den belarusiska nationens bakgrund ställdes mot varandra. Regimens officiella

\footnotetext{
${ }^{5}$ Bland dem återfinns Belarusiska Folkfronten, Förenade Medborgarpartiet, Konservativa Kristdemokratiska Partiet, Belarusiska Vänsterpartiet »Rättvis Värld», De Gröna och dessutom två socialdemokratiska partier.
} 
version utgick från Belarusiska sovjetiska socialistiska republiken (BSSR) och förespråkade att det belarusiska folket är nära besläktat med det ryska. Den motsades av den alternativa versionen som såg den sovjetiska erfarenheten som en parantes i det belarusiska nationsbyggandet. Belarusiska nationalister i allmänhet och Belarusiska Folkfronten (som startade som en antisovjetisk dissidentrörelse) i synnerhet beskriver i stället "en föreställd guldålder i Storfurstendömet Litauen under 1600-talet» som startskottet för den belarusiska nationalismen (Rudling, 2017, s. 79).

Den kortlivade så kallade Belarusiska Folkrepubliken (BNR) 1918-1919 är den centrala punkten i den alternativa nationsberättelsen. Därför har firandet av Dzen'Voli (Frihetsdagen) den 25 mars för att högtidlighålla BNRs självständighetsdeklaration blivit en viktig symbol för oppositionen och deras motstånd mot den sittande regimen. Eftersom regimen (åtminstone inte tidigare) varken erkänt eller uppmärksammat denna högtid blev den ett slags alternativ nationaldag då oppositionella aktörer traditionellt organiserade protestmarscher, demonstrationer och andra event. På Dzen’Voli och andra oppositionella sammankomster syns alltid den alternativa vit-röd-vita fanan med vapenskölden Pahonia, som var den officiella flaggan för BNR. Flaggan härstammar från tidigt 1900-tal och det röda och vita sägs representera de traditionella färgerna på belarusiska folkdräkter och militära banderoller i Storfurstendömet Litauen, Ruthenia och Samogitia (Kotljarchuk, 2020). Under en kort tid efter självständigheten 1991 erkändes den vit-röd-vita flaggan och Pahonia som statssymboler, men efter en kontroversiell folkomröstning återinförde Lukasjenka den röd-gröna flaggan som representerat BSSR.

Användandet av den vit-röd-vita flaggan och Pahonia kom sedermera att beivras eftersom de, enligt Lukasjenka och hans administration, var "fascistiska» symboler. Av detta följde att hela den nationalistiska oppositionen indirekt påstods vara fascister (Bekus, 2010). Dessutom har presidenten ofta i offentliga sammanhang framhållit att oppositionen, särskilt vissa av dem, är nationens fiender - så kalllade "femtekolonnare» betalda av utländska regeringar för att destabilisera landet (Marples 2009, s. 760).

Även många bland befolkningen är mycket kritiska mot oppositionen. Ioffe (2003) menar att detta inte är särskilt konstigt. Han beskriver Belarusiska Folkfronten i synnerhet som arrogant eftersom partiet försökte påtvinga folket en belarusisk nationell identitet som egentligen aldrig existerat. Genom att insistera på att man måste tala belarusiska för att vara "belarusisk» skrämde den nationalistiska oppositionen i praktiken bort den större delen av folket som föredrog att prata ryska. Enligt Ioffe (2007) ledde detta till att många blev närmast "allergiska mot 'BNF: are $^{\prime 6_{\|}}$(s. 39). Det finns också en vittspridd uppfattning att de oppositionella bidragit till sitt eget misslyckande genom att vara oorganiserade, ovilliga att samarbeta, desillusionerade och svaga (Ash, 2015; Korosteleva, 2009; Marples, 2006). Hervouet

${ }^{6} \mathrm{BNF}$ är den förkortning för partiets namn som används på belarusiska. 
(2013) konstaterar att vissa tycker att oppositionella aktörer får skylla sig själva eftersom de fortsätter sin regimkritiska verksamhet fastän de (likaväl som alla andra) vet att det kommer att leda till problem, och kanske till och med statligt våld mot dem.

Även om en hel del av kritiken mot oppositionen säkerligen är berättigad så konstaterar dock Bekus (2010) att den auktoritära kontexten gör att kampen om den belarusiska identiteten utkämpats på mycket ojämlika villkor. Det faktum att den ena nationsberättelsen är en "statlig» nationell idé och den andra alternativa versionen $i$ princip "mot staten" gör att den senare är dömd till att vara i konstant underläge. Det är emellertid intressant att notera att just denna skiljelinje mellan "oppositionella» och »icke-oppositionella» i samhället mjukats upp, säkerligen mycket beroende på att regimen ändrat kurs i frågan. Under 2014 började Lukasjenka, som tidigare alltid framhävt den belarusiska identiteten som del av den rysk-ortodoxa civilisationen, att både i teori och praktik på olika sätt framhäva och främja det belarusiska språket och kulturen, och till och med att introducera delar av arvet från BNR i sin retorik. Denna "mjuka belarusisering» (soft belarusianisation) har både beskrivits som ett försök att distansera sig från Ryssland när relationen mellan länderna tycktes instabil och Lukasjenka därför ville förbättra relationerna med EU (Rudkouski, 2017) och som ett sätt att göra regimen inrikespolitiskt mer legitim utan att behöva göra avsteg från den auktoritära inriktningen.

Det faktum att regimen faktiskt delvis har integrerat delar av den nationalistiska oppositionens retorik, mytologi och historiska representationer (Rudling, 2017) skulle kunna tolkas som att dessa aktörer nu ytterligare marginaliserats eftersom de har fråntagits sin alternativa agenda. Alternativt kan man säga att den nationalistiska oppositionen på vissa sätt faktiskt uppnått några av sina mål eftersom det belarusiska språket och identitetsfrågorna inte längre upplevs som särskilt kontroversiella. ${ }^{7}$ Därmed inte sagt att oppositionen inte fortfarande är illa sedd bland befolkningen: få tror att den skulle kunna styra landet bättre än Lukasjenka. Känslan av att det inte finns några alternativ till det befintliga arrangemanget bidrog till den uppgivenhet som höll det auktoritära systemet vid liv i över 20 år.

\section{Framväxten av »icke-oppositionell» aktivism}

\section{Selektivt förtryck och professionalisering av politiska protester}

En annan process som bidrog till depolitiseringen av det belarusiska samhället är kombinationen av selektiv repression och kontrollerad öppenhet. Genom att framförallt rikta förtrycket mot dem som uttryckligen är politiska, och särskilt dem som öppet utmanade regimen genom gatuprotester, har regimen försökt minska den allmänna motivationen att delta i sådana aktiviteter. De traumatiska minnena från det våldsamma ingripandet mot protesterna 2010 var, till exempel, ett starkt incitament

\footnotetext{
${ }^{7}$ Intryck från författarens fältarbeten i Belarus under perioden 2015-2020.
} 
för att avskräcka de flesta från att delta i protestaktioner, särskilt av offentlig typ (Ash, 2015).

Repressionen i kombination med den upplevda bristen på faktiska resultat har lett till att färre och färre engagerar sig. Enligt Minchenia (2020) har denna utveckling medfört en "professionalisering av aktivismen", som i stället för att drivas av volontärer och gräsrotsaktivister framförallt kommit att utövas av en liten grupp för vilka den politiska kampen blivit deras huvudsakliga sysselsättning. Detta har också gjort att klyftan mellan politiska aktivister och resten av samhället, det vill säga de "opolitiska» medborgarna, blivit ännu mer uttalad. Även inom aktivistsamfundet finns enligt henne också interna motsättningar mellan deltagarna i protestaktioner och ledarna för den politiska oppositionen, som man upplevde var opålitliga och inte gjorde nog i situationer när det verkligen gällde.

Även Navumau (2016) beskriver hur från slutet av 1990-talet själva aktivismen kom att "ritualiseras», då den oppositionella mobiliseringen huvudsakligen kom att begränsas till ett antal symboliskt viktiga historiska datum. Förutom Dzen' Voli återfinns också Dziady (minnesmarsch för stalinrepressionens offer) och en tjernobylmarsch i oppositionens årliga protestkalender. Dessutom noterar han att dessa sammankomster så småningom framförallt kom att bli ett verktyg för oppositionen för att få uppmärksamhet från västländerna. I och med att den oppositionella verksamheten blev alltmer ritualiserad och symbolisk blev den följaktligen än mer irrelevant för allmänheten.

\section{Kontrollerad öppenhet $i$ en samhällelig gråzon}

Det selektiva förtrycket gjorde också att så länge belarusierna höll sig borta från den "smutsiga politiken» kunde de leva ett relativt "normalt liv». Dessutom har de auktoritära myndigheterna under de senaste åren trots allt tillåtit vad som kan beskrivas som en viss grad av kontrollerad öppenhet, samtidigt som de bekämpade den öppna politiska aktivismen. Det har betytt att befolkningen kunnat engagera sig i olika typer av samhälleliga verksamheter - inom till exempel akademin, kultursfären eller miljörörelser - så länge som dessa sågs som opolitiska (Bedford, 2017; Dinerstein, 2019; Poleschuk, 2015). Enligt Dinerstein (2019) var de kulturella evenemang som organiserats av "staten» inte populära bland "det kreativa folket» (s. 8). Samtidigt så var föreläsningar, klasser, klubbar och andra liknande arrangemang välbesökta, framförallt i Minsk men även i andra städer. Skillnaden var att dessa event ägde rum i en slags samhällelig gråzon där arrangörerna och deltagarna varken helt accepterade eller officiellt ifrågasatte den statliga diskursen (Ackermann et al., 2017).

Under dessa förhållanden var det många som inte ens upplevde att de bodde $\mathrm{i}$ en auktoritär stat, eftersom de fortfarande hade möjlighet att fritt och öppet engagera sig i de frågor de intresserade sig för. Att ägna sig åt uttalat politisk aktivism kom dock att ses som något abstrakt, oattraktivt och onödigt, och framförallt något 
som bara den trilska oppositionen sysslade med (Bedford, 2017; Hervouet, 2013). Samtidigt är det möjligt att just denna kontrollerade öppenhet lade grunden till aktivismen, engagemanget och initiativförmågan som blivit drivkraften för protesterna som inleddes 2020. Även om majoriteten av medborgarna i Belarus såg sig som "opolitiska» visar den livliga gräsrotverksamheten under de senare åren tydligt att befolkningen på intet sätt var passiv (Ackermann et al., 2017). I sin analys av olika kulturella identiteter i det moderna Belarus skildrar Dinerstein (2019) också hur många av dem som var aktiva inom kultursektorn upplevde den rådande sociala ordningen i Belarus som orättvis och oacceptabel. De önskade sig förändring och såg sitt eget engagemang i olika offentliga kreativa initiativ (till exempel stadsfestivaler, poesisamhällen, socialt företagande och samhällsentreprenörskap) som ett sätt att själva försöka göra något åt problemet.

\section{Från civilsamhällelig till politisk aktivism}

Redan innan presidentvalet 2020 fanns indikationer på att en "icke-oppositionell» aktivism höll på att utvecklas i samhället genom ett antal lokala protester mot specifika frågor. Ett av de mest uppmärksammade exemplen är den våg av folkliga protester mot den så kallade "parasitskatten" som skakade Belarus i februari-mars 2017. Enligt presidentens Dekret nr 3 »om förebyggande av socialt beroende» måste medborgare som arbetade färre än 183 dagar per år betala en avgift på 180 euro. Detta gällde cirka 10 procent av den arbetsföra befolkningen, och ledde därför till stort missnöje. Enligt Wilson (2018) gjorde regimen detta misstag på grund av den pressande ekonomiska situationen. Douglas (2020, s. 17) noterar också att Lukasjenkas beskrivning av den nuvarande proteströrelsen som en samling "människor med kriminellt förflutet» och "arbetslösa» tyder på att han i allmänhet tycks hysa förakt mot dem som inte har något arbete. Demonstrationerna mot skatten som ägde rum över hela landet tycktes också indirekt riktas mot statens oförmåga att hantera den ekonomiska krisen i allmänhet. Inledningsvis kunde demonstrationerna äga rum i stort sett ostört, men när oppositionen, som försökte dra nytta av denna våg av oroligheter, manade till en stor manifestation i Minsk på Dzen'Voli ledde detta till att restriktiva och repressiva metoder åter sattes in och ett stort antal aktivister greps (Chausov, 2018).

Protesterna mot den kinesiska blybatterifabriken i Brest är ett annat exempel. I flera år har befolkningen demonstrerat mot de föroreningar och hälsorisker som byggandet av fabriken medför. Det senaste året har man uttryckt sitt missnöje genom att träffas varje söndag $i$ en park och fridfullt mata duvorna utan vare sig plakat eller flygblad för att inte ge polisen någon anledning att stoppa deras verksamhet. Både i fallet med parasitskatten och fabriken i Brest kan protesterna anses ha lett till en slags seger för aktivisterna. Skatten genomfördes aldrig och fabriken byggdes men har ännu inte tagits i bruk, vilket kan ha gett intrycket att den auktoritära staten trots allt var mottaglig för den här typen av kritik. 
I parlamentsvalet i november 2019 visade det sig aktivismen också spridit sig till den politiska arenan och antalet "demokratiska nomineringar» till parlamentet var det högsta någonsin (Kostyugova, 2020, s. 130). Ett intressant exempel på civilsamhällesaktivister som blev politiker var den improviserade och kreativa kampanjen som genomfördes av det så kallade "ungdomsblocket» i samma val. Tre ungdomsorganisationer bestämde sig för att delta i valet för att "väcka» sina medstudenter och vänner och visa att politik inte är farligt. ${ }^{8}$ Även om ingen av de demokratiska kandidaterna i slutändan blev invald påpekar Kostyugova (2020, s. 131) att kampanjen trots allt var framgångsrik för dem som förespråkar demokrati eftersom den gav "protestkandidaterna» viktiga erfarenheter som hjälpte dem att förbereda arbetet inför presidentvalskampanjen. Hon skriver också att den aktiva kampanjen ökade politiseringen av samhället och skapade en medvetenhet om de mekanismer som staten använder sig av för att rigga valen. För första gången visade sig även politiska bloggare vara en viktig del av kampanjen. Till exempel fördubblade Siarhej Tsichanouskis blogg "Ett land för livet» antalet abonnenter under parlamentsvalet, bland annat genom att publicera intervjuer med oberoende kandidater.

\section{Försämrad ekonomi, global pandemi och ett brutet "socialt kontrakt»"}

Belarus har ofta presenterats som en ovanlig typ av auktoritär stat på grund av den positiva inställning många i landet ändå tycktes ha till sin president (McAllister \& White, 2016), i folkmun kallad "Bat'ko» (lillefar), "ett familjeöverhuvud som styr sitt land med en rättvis och fast hand" (Rudling, 2017, s. 88). ${ }^{9}$ En vanligt återkommande förklaring till att Lukasjenkas auktoritära system accepterats av medborgarna är förekomsten av ett så kallat "socialt kontrakt» vilket garanterade folket ekonomisk stabilitet och säkerhet i utbyte mot deras lojalitet (Haiduk, Rakova \& Silitski, 2009).

Systemet byggde framförallt på tillgången till kraftigt subventionerad naturgas och råolja från Ryssland som möjliggjorde både att driva den inhemska industrin billigt och att få intäkter genom att återexportera raffinerade oljeprodukter till Västeuropa. Den globala finanskrisen, en försämrad rysk ekonomi på grund av sanktionerna till följd av ockupationen av Krim och fallande oljepriser har fått stor påverkan på den socioekenomiska situationen i Belarus. Tidigare har BNP per capita ökat stadigt men under 2014-2019 var tillväxten noll procent (Guriev, 2020). Lågkonjunkturen 2015-2016 drabbade landet särskilt hårt. Realinkomsterna sjönk avsevärt och väsentligt fler kunde klassificeras som »låginkomstgrupper», vilket indikerar att

\footnotetext{
${ }^{8}$ Författarens intervju i Minsk med representanter för organisationerna Belarusiska studentföreningen, Legalize Belarus och Utjoba vazjneje, december 2019.

${ }^{9}$ Enligt Rudling är denna beteckning också starkt pronationalistisk eftersom Lukasjenka ofta uttrycker att han vill se sin befolkning växa och insisterar på att belarusiska familjer bör ha minst tre barn (Rudling, 2017, s. 88).
} 
befolkningen blev mer sårbar för fattigdom (Bornukova et al., 2019; Sjimanovitj, 2017). Även efter detta har medellönerna inte ökat och inkomstskillnaderna mellan Minsk och andra regioner växt. Också pensionsutbetalningarna har stagnerat och inte höjts i takt med den ständiga inflationen. De flesta pensionärer behöver inte leva i extrem fattigdom, men har heller inte samma höga levnadsstandard som tidigare (Douglas, 2020).

Försöken att reparera det sociala trygghetssystemet som beskrivits som »bräckligt och eländigt» utan att genomföra de grundläggande ekonomiska reformer som behövdes har i stort misslyckats, och ett missnöje har växt fram bland befolkningen (Chulitskaya \& Matonyte, 2018, s. 543). I sin roll som landsfader var det ofrånkomligt att Lukasjenka själv kom att få en del av skulden för detta. Många analytiker påpekade att anledningen till att han inte genomförde de reformer som var nödvändiga för att stärka ekonomin var att de skulle ha försvagat hans egen position (se till exempel Astapenia, 2020; Kłysiński, 2016). Det har också föreslagits att Lukasjenka vägrade förändring eftersom han personligen tycker att marknadsekonomi är ideologiskt oacceptabelt (Moshes \& Nizhnikau, 2017).

När de belarusiska ledarna bestämde sig för att hålla presidentvalet 2020 under rådande förutsättningar verkade de inte ha förstått att Bat'ko inte alls åtnjöt samma legitimitet som tidigare. Hans vårdslösa hanterande av covid-19-pandemin tycks sedan ha blivit den sista spiken i kistan.

För att rädda en redan vacklande ekonomi valde de belarusiska ledarna att hålla samhället öppet under den rådande pandemin. Presidenten visade tydligt att han inte tog covid-19-krisen på allvar. Intervjun där Lukasjenka spelar ishockey och sarkastiskt påpekar att han personligen inte såg några virus "flyga runt» $i$ arenan blev viral (Ruptly, 2020). Han rekommenderade sin befolkning att dricka vodka, basta och köra traktor för att hålla sig friska (Newsflash, 2020). Det faktum att staten tillsynes ignorerade den allvarliga situationen sågs inte med blida ögon av befolkningen.

Droppen som fick bägaren att rinna över för många var när Lukasjenka insisterade på att låta 3000 soldater, inklusive många äldre krigsveteraner, marschera genom Minsk för att fira 75-årsjubileet av Nazitysklands fall. Segerdagen är visserligen en av de viktigaste sekulära helgdagarna i den postsovjetiska regionen, men beslutet att genomföra paraden ger också en indikation om den viktiga roll det så kallade stora fosterländska kriget spelar i regimens politiska retorik och nationsberättelse. Rollen som "segrare» har blivit ett viktigt fundament i regimens version av den belarusiska identiteten (Rudling, 2008). Genom att hålla paraden till varje pris ville Lukajenka visa att regimen inte gav efter för påtryckningar. Många tog i stället detta som en bekräftelse att myndigheterna brydde sig mer om sin egen prestige än de oskyldiga äldre veteranerna som utsattes för onödig fara.

Efter denna händelse verkade fler öppet skeptiska till sin regerings inställning. På civilsamhällesnivå inleddes ett antal omfattande och framgångsrika kampanjer för att på olika sätt stödja dem som bekämpade viruset. Volontärer tillverkade inte bara masker utan medborgarinitiativ, som till exempel \#bycovid19, samlade in 
skyddskläder och olika typer av utrustning till vårdpersonal samt stora summor pengar för att bistå arbetet med pandemin (BelsatTV, 2020). Många tyckte att staten brutit det "sociala kontraktet" genom att stoppa huvudet i sanden och låta medborgarna själva ta ansvar för sitt eget och andras välbefinnande. Den utbredda mobiliseringsandan, i kombination med en allmän frustration över hur covid-19 hanterats, påverkade $\mathrm{i}$ högsta grad valkampanjen och blev katalysatorn för den folkliga resningen.

\section{Valspelet som blev på allvar}

\section{Nya aktörer och nytt hopp}

Lukasjenka missbedömde situationen gravt när han mitt i den pågående pandemin meddelade att presidentval skulle hållas i Belarus den 9 augusti, det vill säga till och med två veckor tidigare än vad som tidigare fastställts. Vid en första anblick kunde man få intrycket att beslutet fick avsett resultat. Försöken att demokratiskt välja en gemensam kandidat som skulle representera alla oppositionella aktörer gick om intet när de primärval oppositionspartierna planerat att hålla över hela landet ställdes in på grund av smittrisken.

Mot bakgrund av diskussionen ovan kan det likväl konstateras att det var få $\mathrm{i}$ befolkningen som egentligen brydde sig om huruvida den traditionella oppositionen lyckades hitta en gemensam kandidat eller inte. Däremot väckte nyheten att Viktar Babaryka, tidigare styrelseordförande i Belgazprombank och Valeryj Tsapkala, före detta ambassadör i USA (senare grundare av High Technologies Park i Minsk) skulle kandidera i valet stor uppmärksamhet. Likaså fick tillkännagivandet från den populäre videobloggaren Siarhej Tsichanouski att han också skulle ställa upp i presidentvalet mycket positiv respons. Inte överraskande arresterades Tsichanouski därför kort efter att lanserat sin kandidatur och det blev som bekant i stället hans fru Svjatlana Tsichanouskaja som tog över hans valkampanj.

Tsichanouski blev först känd när han reste runt och pratade med folk över hela landet och sedan publicerade intervjuerna på sin YouTube-kanal. Många av dem han mötte uttryckte stor frustration över sin livssituation. En av de mest uppmärksammade intervjuerna var med en arg gammal dam som jämförde Lukasjenka med en kackerlacka och sa att det enda sättet att bli av med sådana skadedjur var att klappa till dem med en badtoffel (Shkliarov, 2020). "Stoppa kackerlackan» blev sedermera Tsichanouskis valslogan och symboliken fortsatte att vara viktig under hela valprocessen. Många viftade till exempel med flip-flops eller tofflor under de olika evenemang som anordnades under kampanjen.

En viktig pusselbit för att förstå den fortsatta utvecklingen är att varken Tsichanouskaja, Babaryka och Tsapkala förknippades med den konventionella oppositionen, vilket gjorde dem mer trovärdiga i mångas ögon. Eftersom både Babaryka och Tsapkala uppfattades som del av "etablissemanget» fick många intrycket att de kunde innebära en riktig utmaning för Lukasjenkas system. Troligtvis var det därför 
som ingen av deras kandidaturer godkändes. Myndigheterna försökte försäkra sig om att de inte skulle utgöra något hot. Liksom Tsichanouski fängslades till sist även Babaryka, anklagad för ekonomisk brottslighet. Tsapkala flydde landet för att inte gripas. Svjatlana Tsichanouskaja blev däremot, överraskande nog, registrerad som presidentkandidat. Det var förvånande eftersom insamlingen av de 100000 signaturer som behövs för att kunna lämna in ansökan om att kandidera visade att hon hade mångas sympatier. Över hela landet köade folk för att lämna sin underskrift och visa sitt stöd för hennes och hennes mans kampanj. Det framstår i efterhand som att Lukasjenkas administration underskattade henne. Eftersom hon var kvinna och dessutom hemmafru (men även lärare) utan tidigare politisk erfarenhet antog de att hon inte skulle kapitalisera stödet från befolkningen. I själva verket blev hennes valkampanj en enorm framgångssaga, mycket på grund av samarbetet med Maryia Kalesnikava (Babarykas kampanjledare) och Veranika Tsapkala (Tsapkalas fru).

\section{En föränderlig befolkning mot en oföränderlig president}

Tillsammans bildade de tre kvinnorna en fotogenisk och till synes oövervinnerlig trio som ingöt hopp i samhället och verkligen visade att "kvinnor kan». Genusaspekten blev också en viktig och integrerad del av konflikten mellan proteströrelsen och Lukasjenka. I sociala medier syns tydligt att många kvinnor var trötta på presidentens öppna manschauvinism och hans vana att försöka förminska kvinnor. ${ }^{10} \mathrm{Efter}$ att Lukasjenka - ännu en gång - i juli 2020 uttalat sig om att kvinnor inte är lämpade att bli presidenter publicerades till exempel en video där 42 belarusiskor avfärdar några av hans mest ökända kommentarer. "En kvinnas kall är att dekorera världen»; »En kvinna bör vara $165-175 \mathrm{~cm}$ lång»; " $O \mathrm{~m}$ du tynger ner en kvinna med konstitutionen kommer hon att ramla omkull - den stackaren» är några av de fraser som bemöts $\mathrm{i}$ videon som sågs av 3,5 miljoner på fyra dagar (Vaisman, 2020).

Samarbetet mellan Tsichanouskaja, Tsapkala och Kalesnikava visade både i bilder och handling att belarusiska kvinnor ansåg sig redo att spela huvudrollen i samhällets omvandling. Kvinnorna har också kommit att spela en viktig roll i protesterna. När demonstrationerna efter valet tycktes vara på upphällningen på grund av polisens övervåld var det kvinnorna som såg till att de fortsatte. Eftersom polisen åtminstone tidigare var mindre aggressiv mot kvinnliga deltagare kunde de bilda solidaritetskedjor som skyddade männen och gav nytt liv åt den fredliga motståndsrörelsen.

Det finns också indikationer på att det otidsenliga och statiska system som Lukasjenka representerar inte bara förlorat sin legitimitet bland kvinnor utan bland

\footnotetext{
${ }^{10}$ Roligt, men sorgligt är det ironiska test där läsaren enligt redaktionen för Studentskaya Dumka kan kontrollera hur väl hen känner till presidentens syn på en modern kvinna: https://dumka.me/ test/lukashenko. Ett annat exempel är detta där »kvinnor» bytts ut mot "män» i några av Lukasjenkas mest kända uttalanden: https://nash-dom.info/58678
} 
den yngre befolkningen i allmänhet. Douglas (2020) skriver att Lukasjenka gjort sig extra impopulär bland de yngre under senare år genom att införa inte bara "parasitlagen» utan också en skärpning av lagstiftningen om innehav av droger och en begränsning av unga mäns rätt att skjuta upp sin obligatoriska militärtjänst. I en rapport från 2019 skriver Moshes och Nizhnikau att Lukasjenka

\footnotetext{
har uppenbara svårigheter att inse att det land där han kom till makten för ett kvarts sekel sedan, och det land där han styr idag, inte är det samma (...) Med tiden kommer kontrasten mellan det bakåtsträvande presidentskapet och det moderniserande samhället att bli allt starkare och förr eller senare lär konflikten bli uppenbar (Moshes \& Nizhnikau, 2019, s. 3).
}

I en opinionsundersökning genomförd i januari 2020 fann även O’Loughlin, Toal och Bakke (2020) att till skillnad från den äldre generationen sa sig en stor del av dem under 45 år föredra västerländsk demokrati framför den nuvarande modellen. Dessa förkastar helt sovjetiska traditioner och motsätter sig också Lukasjenkas styre.

Det är ännu inte möjligt att säga om det är just denna utveckling som orsakat och drivit proteströrelsen. Under hela valkampanjen har emellertid sociala medier förmedlat bilden av Lukasjenka som en president som inte längre är populär och till och med äcklar befolkningen. Först beskrevs han som kackerlacka av Tsichanouski och efter att oberoende belarusiska medier publicerat resultatet av en informell valundersökning som tydde på att hans stöd bland befolkningen var extremt lågt fylldes internet av memes som hånade »Sasja 3\%» som blev Lukasjenkas nya öknamn. Ofta sågs referenser till "Psyko 3\%» som en hänvisning till hans insisterande på att coronavirus bara är en "psykos". Eftersom det inte finns någon tillförlitlig information om vilket stöd det auktoritära systemet faktiskt har, eller inte har, fyllde dessa memes en viktig funktion. De fick inte bara folk att skratta, de spred också budskapet att presidentens anhängare var i minoritet. I den bemärkelsen bidrog de till att delegitimera Lukasjenkas styre och sprida hopp om att politiska förändringar var inom räckhåll.

\section{En unik valkampanj men ett välbekant falskt valresultat}

Det var inte bara de intensiva protesterna mot resultatet som var unika i presidentvalet 2020 utan valet föregicks också av en mycket ovanlig valkampanj, där "vanliga», tidigare opolitiska invånare plötsligt öppet uttryckte sin önskan om förändring. För första gången någonsin engagerade sig folk över hela landet, inte bara i Minsk, i den politiska processen. De gick på valmöten, de delade sina politiska åsikter på sociala medier och, viktigast av allt, de röstade i slutändan förTsichanouskaja. Den politiska aktivismen blev synlig på ett helt annat sätt än tidigare, både på sociala medier och på gator och torg under det som har kallats för "protestsommaren". När över 60000 människor samlades i en park i Minsk den 30 juli för att stödja Tsichanouskajas valkampanj var det den största politiska händelsen i Belarus sedan 1991. Även valdagen såg mycket mer aktivitet än något annat val i landets historia. Långa köer ringlade 
till vallokalerna och ett stort antal av dem som väntade bar det vita armband som kommit att bli en symbol för Tsichanouskajas kandidatur.

Det officiella valresultatet, som gav Lukasjenka 80 procent av rösterna, jämfört med Tsichanouskajas 10 procent, avspeglade inte alls det enorma stöd för Tsichanouskaja som framkommit under sommarens kampanj. Inga oberoende internationella valövervakare fanns på plats och nationella observatörer tilläts i många fall inte ens att uppehålla sig i röstlokalerna, officiellt på grund av pandemin. Trots detta råder inget tvivel om att massivt valfusk, precis som vanligt, förekom. Data från de olika plattformar där Tsichanouskajas väljare uppmanats att registrera sin röst, som Golos (Röst), Zubr och Tjestnije Ljudi (Ärliga människor) visar både att Lukasjenka omöjligen kan ha fått 80 procent av rösterna och att det är troligt att Tsichanouskaja hade stöd av en majoritet (Rudnik, 2020; Voice of Belarus, 2020). Även OSSE:s rapportör konstaterar att valet inte uppfyllde de grundläggande krav som fastställts efter tidigare valövervakningsmissioner och att presidentvalet inte var varken transparent, fritt eller rättvist (Benedek, 2020).

Troligtvis var folkets röst på Tsichanouskaja snarast en röst mot Lukasjenka. Hon upprepade konsekvent att hon inte ville bli president och endast önskade att hennes man skulle släppas fri och att landet skulle hålla demokratiska val. Dynamiken i proteströrelsen efter valet visar också tydligt att dess huvudsakliga mål inte egentligen är att Tsichanouskaja ska bli president utan snarare att åstadkomma ett systemskifte och få bort Lukasjenka från makten. Proteströrelsen har därför också i stort sett varit ledarlös - varken Tsichanouskaja eller någon av de andra två kvinnorna som ledde valkampanjen har tagit på sig en central roll. Ändå var det Tsichanouskajas kampanj som gav folket hopp om att kunna påverka utvecklingen. Den inspirerade dem att rösta, vilket i sin tur är anledningen till protesternas omfattning och styrka.

\section{Efter valet: ny dynamik i det belarusiska samhället}

\section{En svårhanterlig, ledarlös och dynamisk proteströrelse}

Som nämndes inledningsvis var tidigare valprotester i Belarus relativt småskaliga, både räknat i antal deltagare och i geografisk spridning, och kunde därför också lätt upplösas när polisen brutalt ingrep. Den här gången ifrågasattes valresultatet på många olika platser över hela landet och demonstranterna var orubbliga. Trots att de konstant möttes (och i skrivande stund fortfarande möts) av trakasserier och polisinsatser är protestandan efter ett halvår fortfarande stark. Storskaliga protestmarscher genomförs varje helg både i Minsk och andra städer, även om antalet deltagare har minskat avsevärt från cirka 200000 när de var som störst till flera tusen i december (Onuch, 2020).

Den här gången är heller inte mobiliseringen centraliserad på samma sätt som tidigare utan det handlar mer om en eklektisk civil motståndsrörelse. Man har inte försökt bygga något tältläger på centrala platser à la Majdan. I stället har demonstranterna inspirerats av proteströrelsen i Hongkong och strävar efter att ha aktiviteter på många olika ställen samtidigt för att göra det svårare för polisen att fokusera 
resurser och stoppa utvecklingen. Vid sidan av marscher och demonstrationer har en rad andra, både kollektiva och individuella, protestaktiviteter utvecklats - inte sällan relaterade till att i olika situationer framhäva den vit-röd-vita flaggan. Utvecklingen har genererat ett stort antal självorganiserade protestgrupper som verkar bland annat i olika stadsdelar, på universitet eller arbetsplatser. Grupperna utför regelbundet lokala protestaktiviteter och många har till och med designat egna logotyper och protestflaggor (Herasimenka, 2020; Liubakova, 2020).

Snabbmeddelandeappen Telegram har varit ett viktigt verktyg för att kommunicera, organisera och sprida information om olika aktiviteter bland protestdeltagare både innan och efter valet. Fördelen med denna app är att den även fungerar när myndigheterna "stänger av» dataanvändning via mobilnätet vilket de bland annat gjorde veckan efter presidentvalet den 9 augusti, och sedan fortsatt att göra med jämna mellanrum när de anser det strategiskt viktigt att förhindra kommunikationen mellan demonstranterna.

Den Warszawa-baserade telegramkanalen Nexta har kommit att få stor betydelse inte bara för samordningen av protester och spridandet av information utan också för den strategiska planeringen av motståndet mot Lukasjenka. I augusti hade kanalen över 2 millioner abonnenter och var en av de mest populära telegramkanalerna i världen (Edwards, 2020). Likväl påpekar Herasimenka och kolleger (2020) att man inte ska överskatta den roll som online-plattformar spelat för protesternas framgång. Snarare, menar de, har det faktum att mobiliseringen också har en stark "offline»-komponent, till exempel i form av samverkan med grannar eller vänner, bidragit till att utvidga och upprätthålla proteströrelsen. En intressant utveckling är beskrivningen av de informella nätverk som börjat uppstå mellan de många kvinnor som anhålls i samband med protesterna. Trots deras olika bakgrunder och erfarenheter uppstår ett slags "systerskap i fångenskap» och många håller kontakten även efter att de släppts fria. ${ }^{11}$

\section{Sprickor $i$ det autokratiska fundamentet}

Enligt den akademiska litteraturen om "auktoritär konsolidering» så vilar den auktoritära regimens stabilitet på tre pelare: förtryck (användning av tvång), kooptering (förmåner till vissa grupper så att de inte motsätter sig systemet) och slutligen legitimering (att få medborgarna att acceptera eller åtminstone tolerera regimen) (Gerschewski, 2013). Före 2020 accepterade majoriteten i Belarus den politiska situationen på grund av rädslan för repressalier, löftet om ett socialt och finansiellt skyddsnät i utbyte mot deras lojalitet och en känsla av att det saknades politiska alternativ.

Just nu verkar emellertid sockeln för det belarusiska auktoritära systemet ytterst instabil. Kooptering tycks fortfarande delvis fungera för att hålla regimen vid liv,

${ }^{11}$ Författarens intervju med en tidigare häktad feministisk aktivist, november 2020. 
åtminstone inom vissa grupper. Även om det är oklart i vilken utsträckning den politiska eliten stöder presidenten står de flesta inom polis, militär och specialstyrkor plikttroget vid Lukasjenkas sida och upprätthåller förtrycket. I mitten av november hade 25000 personer gripits för att ha deltagit i manifestationerna, många har därefter åtalats och fängslats. Ett stort antal av dem som arresterats vittnar om tortyr (Human Rights Watch, 2021). Polisen har också använt oproportionerligt våld på gatorna, och enligt människorättsorganisationen Vjasna har minst tre demonstranter dött till följd av polisens användning av vapen, eller underlåtenhet att tillhandahålla medicinsk vård i tid (Human Rights Center Viasna, 2020).

Trots detta tycks myndigheterna inte riktigt veta hur de ska hantera situationen. Motståndets dynamiska och decentraliserade karaktär gör det svårt att få bukt med protesterna. Den selektiva repression som tidigare användes mot alla som krävde förändring är inte lika effektiv när en så stor del av befolkningen har politiserats. Myndigheterna har särskilt riktat in sig på dem som möjligen kan ses som ledare för proteströrelsen - styrelseledamöterna i samordningsrådet skapat för att leda förhandlingar med Lukasjenka om maktöverföring. Enligt statlig propaganda förbereder rådet en statskupp och flera av dem har därför arresterats och resten, inklusive Tsichanouskaja, har tvingats att fly landet.

Statens brutala reaktion på protesterna efter valet skadade också Lukasjenkas legitimitet, eftersom många tidigare nog inte trott att presidenten skulle tillgripa våld mot sina egna medborgare för att säkra sin position. En undersökning i december 2020 visar att 80 procent av demonstranterna rapporterar att det var just våldet som fick dem att engagera sig (Krawatzek \& Sasse, 2020). Även tidigare under hösten visade videon där hundratals arbetare på traktorfabriken MZKT i Minsk jublar och ropar "Avgå» eller "Försvinn" (uchodi) att Lukasjenka inte längre helt kan förlita sig på stödet från sina kärnväljare (Scollon, 2020). Arbetare vid flera företag, bland dem några stora statliga fabriker, anslöt sig till en riksomfattande strejk till stöd för protesterna. Att de flesta tvingats återvända till arbetet är också signifikant eftersom det signalerar att "förtryck» är det enda instrument som finns kvar i den auktoritära verktygslådan. Forskningen visar dock tydligt att auktoritära ledare inte kan förlita sig enbart på förtryck för att hålla sig kvar vid makten. De måste på olika sätt försöka övertyga befolkningen att deras styre är legitimt (Guriev \& Treisman, 2015). I detta avseende verkar den belarusiska auktoritära statens fundament ha fått livshotande skador.

\section{Uppraknandet av en politiserad rysktalande belarusisk nation}

Det är intressant att notera att symbolen för proteströrelsen som domineras av aktivism på gräsrotsnivå har blivit »den traditionella oppositionens» vit-röd-vita flagga tillsammans med Pahonias. ${ }^{12}$ Att den synliga majoriteten av demonstranterna är

\footnotetext{
${ }^{12}$ I början tenderade demonstranterna att använda både den rödgröna och den vit-röd-vita flaggan. Ofta bars båda flaggorna av samma person eller ett par som en symbol för nationell enhet. Senare kom den vit-röd-vita flaggan att dominera.
} 
rysktalande ser Kazharski (2021, s. 7) som ett tecken på att en ny slags hybrid har fötts: »en rysktalande eller tvåspråkig politisk rörelse under en flagga som tidigare associerades med en mycket mer etnokulturell opposition». Det intressanta är emellertid att enligt Kazharski har protesterna kommit att kallas "Belarus uppvaknande 2020» vilket onekligen för tankarna till Belarusiska Folkfronten och de belarusisktalande nationalisternas samhälleliga projekt.

En av anledningarna till Tsichanouskajas popularitet var just att hon inte hade den nationella identiteten som huvudpunkt på programmet. Det var attraktivt för den stora del av befolkningen som sett den envisa kamp för det belarusiska språket och kulturen som förts av oppositionen, och likaså deras "ryssofobi», som abstrakt och onödig, minst sagt (Burkhardt, 2016). Undersökningar både innan (Krawatzek, 2019) och efter valet (Chatham House, 2020) visar tydligt att en majoritet inte tycker att Belarus bör ha goda relationer med antingen Ryssland eller EU utan att $b a ̊ d a$ är att föredra. Tsichanouskaja pratade nästan alltid ryska i sina framträdanden och kampanjen skulle kunna sägas illustrera vad Fabrykant (2019) kallat rysktalande belarusisk nationalism. Även om Tsichanouskaja förstås poängterade att Belarus är ett självständigt land så var den geopolitiska agendan påfallande frånvarande både under hennes kampanj och protesterna som följde. Budskapet handlade om fria val och demokrati - inte om att välja mellan Ryssland och Europa (Kazharski, 2021).

Kanske är det därför det militära understöd från Ryssland som Lukasjenka flera gånger hotat med inte ännu förverkligats. I princip ser de två befolkningarna varandra som brödrafolk. Givetvis skulle det för Kreml inte statuera något bra exempel för den ryska oppositionen om den auktoritära regimen i Belarus kollapsade på grund av demonstranternas tryck, men ett militärt ingripande skulle heller inte främja Putins popularitet varken på hemmaplan eller i Belarus. Eftersom ländernas ekonomier är tätt sammankopplade är det dessutom inte troligt att Belarus skulle kunna, eller ens vilja, fjärma sig från Ryssland även om de "demokratiska krafterna» tar över. Så länge protesterna är fredliga är det därför mer sannolikt att Rysslands stöd till Lukasjenka framförallt är ekonomiskt. Genom att Ryssland på detta vis räddar Belarus från ekonomisk kollaps, och revolution, försätts Lukasjenka i en beroendeställning som hindrar honom från att till exempel åter försöka närma sig EU på det sätt han gjorde runt $2015 .{ }^{13}$

\section{Slutsatser och scenarier}

Den här artikeln kan sägas illustrera två konkreta exempel på vad osäkerhetens politik innebär och kan leda till. Det första relaterar till aktörerna. Generellt bidrar samspelet mellan den styrande eliten, oppositionen och väljarna i odemokratiska

\footnotetext{
${ }^{13}$ Relationen mellan Belarus och Ryssland har länge varit instabil, och vissa analytiker anser att Putin egentligen har tröttnat på Lukasjenka och hans upptåg och letar efter en lämplig och acceptabel ersättare (EurActiv, 2020; Rainsford, 2020).
} 
val till att stärka den auktoritära staten. Men från fallet Belarus framgår att om den grundläggande dynamiken, eller maktförhållandena mellan parterna, på något sätt förändras kan det bli startskottet för en successiv eller plötslig förändringsprocess. I Belarus hade de auktoritära ledarna lyckats få de allra flesta att uppfatta "politik» i allmänhet och valen i synnerhet som ointressanta och irrelevanta. Folk i allmänhet brydde sig inte ens nödvändigtvis om att rösta och hade därför inte heller särskilt stort intresse av att invända mot resultatet. Idag är situationen den omvända och de som tidigare aktivt avskärmade sig från politiken har blivit en viktig del av proteströrelsen.

Utvecklingen i Belarus illustrerar även hur sårbar den auktoritära regimen är när dess legitimitet öppet ifrågasätts. Enligt teorin om osäkerhetens politik så framstår hegemoniska stater ofta som oangripbara, trots att det i själva verket finns ett antal hot mot deras stabilitet som ligger latenta. När sådana hot blir synliga blir de ofta effektiva verktyg för kollektiva protester och används för att utkräva ansvar och framhäva regimens svaghet. Ekonomiska kriser och samhällsklyftor är två exempel i litteraturen - båda är relevanta för utvecklingen i Belarus. Före 2020 accepterade många den politiska situationen på grund av det sociala kontraktet. När den auktoritära regimen inte kunde leverera blev deras situation prekär och covid-19-katastrofen förstärkte känslan av att Lukasjenka brutit kontraktet. Vidare har protesterna också kommit att framhäva kontrasten mellan det föråldrade samhälle som Lukasjenka representerar och de ungas krav på förändring.

Det finns anledning att tro att protesternas intensitet och motståndskraft bygger på att demonstranterna faktiskt röstade i presidentvalet - de protesterar i praktiken mot att deras röster blev stulna. Efter valen 2006 och 2010 uppmanade oppositionen till protester mot valresultat som utan tvekan också var manipulerade. Det är emellertid tveksamt om det vid de tillfällena fanns en kandidat som verkligen konkurrerade med Lukasjenka om presidentposten. Det är inte självklart eftersom folk i allmänhet inte nödvändigtvis brydde sig om att rösta. Den här gången verkar det som att Tsichanouskaja fick folkets röst, och därför har protesterna en helt annan omfattning.

Det är svårt att veta hur »revolutionen» kommer att utvecklas, men dynamiken i protestsituationen gör det möjligt att generera olika scenarier. Kleins och Regans (2018) modell fokuserar på hur demonstranternas olika beteenden och strategier genererar olika typer av "kostnader» för staten. Så länge demonstranternas enda krav är att Lukasjenka ska avgå uppfattas detta, enligt modellen, som en alltför hög politisk "eftergiftskostnad» (concession cost) från regimens sida. Maximalistiska krav på att totalt förändra politiskt status quo ses som »dyra» att tillgodose politiskt. Därför är det mer troligt att staten försöker kväsa protesterna än går dem till mötes, vilket kan förklara den stora mängd våld den belarusiska regimens sida redan använt. Om demonstranterna skulle vara beredda att diskutera andra utfall, till exempel nyval där Lukasjenka kan ställa upp eller de framtida konstitutionella reformer som presidenten länge påstått ska genomföras om 1-2 år, skulle deras krav framstå som 
mindre kostsamma. Eftersom proteströrelsen bygger på att Tsichanouskaja vann valet framstår detta dock inte som en trolig utveckling.

Ett annat scenario är att demonstranterna genom utökade strejker och demonstrationer lyckas generera stora störningskostnader (disruption costs) som gör att staten tvingas till eftergifter. Protesterna kan till exempel göra den ekonomiska situationen i landet instabil genom att påverka affärsverksamhet och import- och exportflöden. De kan också skapa oreda i landets allmänna ordning genom att exempelvis blockera kollektivtrafiken, viktiga byggnader eller vägar och infartsleder. Enligt teorin har protester som alstrar kostnader av den här typen störst chans att få staten att tillmötesgå demonstranternas krav. Just nu verkar emellertid inte störningskostnaderna vara tillräckligt höga. Den belarusiska rubeln har visserligen minskat i värde, en del internationella företag har redan flyttat, eller hotar att flytta sin verksamhet ur landet och om detta eskalerar skulle det påverka den redan dåliga ekonomiska situationen och Lukasjenkas ställning. Emellertid tycks strejkvapnet förlorat fart och med rysk hjälp, både på ett finansiellt plan och med arbetskraft för att ersätta viktiga samhällsaktörer som "bytt sida» (Luxmore, 2020), tycks Lukasjenka fortfarande kunna upprätthålla sitt stödsystem åtminstone kortsiktigt.

Ett slutligt scenario är att revolutionen övergår i en slags politisk evolution. Politisk förändring i Belarus lär inte ske över en natt, men den explosionsartade ökningen av politiskt deltagande och medborgerlig aktivism är ett gott tecken. Den auktoritära staten upprätthölls av att de flesta "gillade det autokratiska läget» (Gel'man, 2010) och ansåg att politik var "någon annans" problem. I detta avseende har det politiska status quo redan förändrats till det bättre. Dessutom har försök att bygga upp en politisk plattform med proteströrelsen som bas inletts (BelarusFeed, 2020). Även om Lukasjenka vägrar kompromissa så har den elektorala autokratin lidit svåra nederlag. Valresultatet erkänns inte av EU (European Council, 2020) och många europeiska ledare vägrar acceptera hans presidentskap (Government of Iceland, 2020). Det är dessutom inte särskilt sannolikt att de som protesterar idag någonsin kommer att acceptera "valspelet» $\mathrm{i}$ sin tidigare form.

Förr eller senare måste någon typ av åtgärder till för att försöka återupprätta den demokratiska fasaden. Vare sig det blir att genomföra de konstitutionsförändringar som Lukasjenka sedan länge utlovat, eller att hålla val, så lär politiseringen av samhället göra det svårt, för att inte säga omöjligt för Lukasjenka att återskapa den legitimitet och stabilitet som kännetecknade hans auktoritära regim. Om det dessutom finns ett trovärdigt politiskt alternativ, och kanske till och med en kandidat som Ryssland kan acceptera, så är det möjligt att detta kan leda till demokratisering "av misstag» (Treisman, 2017). Det vill säga att förändring kommer att ske även om det inte var Lukasjenkas intention. Oavsett den elektorala revolutionens utgång är därför den mobilisering och politisering som utlöstes av presidentvalet troligtvis det farligaste hot som den auktoritära regimen i Belarus någonsin ställts inför. 


\section{Om artikeln}

Jag är mycket tacksam för den konstruktiva kritik och konkreta förbättringsförslag jag fick från de två anonyma granskarna. Ett stort tack också till Ryhor Nizhnikau för moraliskt stöd och all hjälp med att aktualisera litteraturlistan. Slutligen vill jag uttrycka min tacksamhet för det resestipendium jag fick från Svenska Institutets Visbyprogram som möjliggjorde mina forskningsresor till Belarus under 2019 och 2020. En tidigare version av den här artikeln publicerades i Östbulletinen nr. 3, årgång 24, 2020.

\section{Referenser}

Ackermann, F., Berman, M. \& Sasunkevich, O. (2017). In search of agency: Examining Belarusian society from below. Fournal of Soviet and Post-Soviet Politics and Society, 3(1), 1-18.

Ash, K. (2015). The election trap: The cycle of post-electoral repression and opposition fragmentation in Lukashenko's Belarus. Democratization, 22(6), 1030-1053.

Astapenia, R. (2020, 18. februari). Lukashenka's commitment to Belarusian sovereignty is overstated. Chatham House. Hämtat 28. mars 2021 från https://www.chathamhouse.org/2020/02/lukashenkas-commitmentbelarusian-sovereignty-overstated

Astapova, A. (2017). Rumor, humor, and other forms of election folklore in non-democratic societies: The case of Belarus. Folklore: Electronic Fournal of Folklore, 69, 15-48.

Bedford, S. (2017). 'The election game' authoritarian consolidation processes in Belarus. Demokratizatsiya: The Fournal of Post-Soviet Democratization, 25(4), 381-405.

Bekus, N. (2010). Struggle over identity: The official and the alternative 'Belarusianness'. Central European University Press.

BelarusFeed. (2020, 1. september). Belarus opposition leaders Kolesnikova and Babariko creating new political party. Hämtat 9. oktober 2020 från https://belarusfeed.com/opposition-kolesnikova-babariko-politicalparty/

BelsatTV. (2020, 8. april). \#ByCovid19: Volunteers launch website to support Belarusian doctors. Hämtat 30. mars från https://naviny.belsat.eu/en/news/bycovid19-volunteers-launch-website-to-support-belarusiandoctors/

Benedek, W. (2020). OSCE Rapporteur's report under the Moscow mechanism on alleged human rights violations related to the presidential elections of 9 august 2020 in Belarus. ODIHR. Hämtat 28. mars 2021 från https:// www.osce.org/files/f/documents/2/b/469539.pdf

Bornukova, K., Cojocaru, A., Matytsin, M. \& Shymanovich, G. (2019). Poverty, vulnerability, and household coping strategies during the 2015-16 recession in Belarus. Policy Research Working Paper 9003. World Bank Group. Hämtat 28. mars 2021 från http://beroc.by/upload/iblock/d76/d7603506057422bc020e4067 f42989c9.pdf

Bunce, V. \& Wolchik, S. (2006). Favorable conditions and electoral revolutions. fournal of Democracy, 17(4), $5-18$.

Burkhardt, F. (2016). Concepts of the nation and legitimation in Belarus. I M. Brusis, J. Ahrens \& M. Schulze Wessel (red.), Politics and legitimacy in Post-Soviet Eurasia (s. 148-171). Palgrave Macmillan.

Charnysh, V. \& Kulakevich, T. (2016). Belarusian political parties: Organizational structures and practices. I K. Sobolewska-Myślik, B. Kosowska-Gąstoł \& P. Borowiec (red.), Comparing organizational structures of political parties in Central and Eastern European countries (s. 41-58). Jagiellonian University Press.

Chatham House. (2020). Belarusians'views on the political crisis:Results of a public opinion poll conducted between 13 and 18 November 2020. Hämtat 28. mars 2021 från https://drive.google.com/file/d/1VVEfR3raAIkJr MRo-t_vkjOzNmrhDKvN/view

Chausov, Y. (2018). Civil society: spring shocks unable to reverse past trends. I A. Pankovski \& V. Kostyugova (red.), Belarusian yearbook 2018: a survey and analysis of developments in the Republic of Belarus in 2017. Hämtat 28. mars 2021 från https://nmnby.eu/yearbook/2018/en/page12.html

Chulitskaya, T. \& Matonyte, I. (2018). Social security discourses in a non-democratic state: Belarus between Soviet paternalistic legacies and neo-liberal pressures. Viešoji politika ir administravimas, 17(4), 539-554. 
Dinerstein, A. (2019). Cultural identity in modern-day Belarusian discourse on public creativity. fournal of International and Intercultural Communication, 14 (1), 41-59.

Douglas, N. (2020). Belarus: from the old social contract to a new social identity. ZOiS Report 6/2020. Hämtat 28. mars 2021 från https:/en.zois-berlin.de/fileadmin/media/Dateien/3-Publikationen/ZOiS_ Reports/2020/ZOiS_Report_6_2020.pdf

Edwards, M. (2020, 18. augusti). How one Telegram channel became central to Belarus' protests. GlobalVoices. https:/globalvoices.org/2020/08/18/how-one-telegram-channel-became-central-to-belarus-protests/

EurActiv. (2020, 20. augusti). Putin's unexpected dilemma: what to do with Lukashenko? Hämtat 28. mars 2021 från https:/www.euractiv.com/section/europe-s-east/news/putins-unexpected-dilemma-what-to-do-withlukashenko/

European Council/Council of the European Union. (2020, 24. september). Belarus: Declaration by the High Representative on behalf of the European Union on the so-called 'inauguration' of Aleksandr Lukashenko. Hämtat 28. mars 2021 från https://www.consilium.europa.eu/en/press/press-releases/2020/09/24/ belarus-declaration-by-the-high-representative-on-behalf-of-the-european-union-on-the-so-calledinauguration-of-aleksandr-lukashenko/

Fabrykant, M. (2019). Russian-speaking Belarusian nationalism: An ethnolinguistic identity without a language? Europe-Asia Studies, 71(1), 117-136.

Gel'man, V. (2010). Regime changes despite legitimacy crises: Exit, voice, and loyalty in post-communist Russia. Fournal of Eurasian Studies, 1(1), 54-63.

Gerschewski, J. (2013). The three pillars of stability: Legitimation, repression, and co-optation in autocratic regimes. Democratization, 20(1), 13-38.

Government of Iceland. (2020, 11. augusti). Joint statement of Nordic-Baltic foreign ministers on recent developments in Belarus. Hämtat 28. mars 2021 från https://www.stjornarradid.is/library/04-Raduneytin/ Utanrikisraduneytid/PDF-skjol/NB8\%20statement\%20Belarus.pdf

Guriev, S. (2020). The political economy of the Belarusian crisis. Intereconomics: Review of European Economic Policy, 55(5), 274-275.

Guriev, S. \& Treisman, D. (2015). How modern dictators survive: An informational theory of the new authoritarianism. NBER Working Paper 21136. Hämtat 28. mars 2021 från https://www.nber.org/papers/ w21136.pdf

Hadenius, A. \& Teorell, J. (2007). Pathways from authoritarianism. Fournal of Democracy, 18(1), $143-157$.

Haiduk, K., Rakova, E. \& Silitski, V. (2009). Social contracts in contemporary Belarus. Belarusian Institute for Strategic Studies.

Herasimenka, A. [@alesherasimenka]. (2020, 15. september). 5 weeks of Belarus Protest. Summary [videos attached] [tweet]. Twitter. https://twitter.com/alesherasimenka/status/1305978471538196480

Herasimenka, A., Lokot, T., Onuch, O. \& Wijermars, M. (2020, 11. september). There's more to Belarus's 'Telegram Revolution' than a cellphone app. Washington Post. Hämtat 7. februari 2021 från https://www. washingtonpost.com/politics/2020/09/11/theres-more-belaruss-telegram-revolution-than-cellphone-app/

Hervouet, R. (2013). Authoritarianism from below: Lessons from ethnographic studies in Belarus. Anthropology of East Europe Review, 31(2), 19-29.

Human Rights Center Viasna. (2020). Human rights situation in Belarus August 2020. Hämtat 9 oktober 2020 från http://spring96.org/en/news/99352

Human Rights Watch. (2021). Belarus: Events of 2020. I World Report 2021. Hämtat 28. mars 2021 från https:// www.hrw.org/world-report/2021/country-chapters/belarus

Ioffe, G. (2003). Understanding Belarus: Questions of language. Europe-Asia Studies, 55(7), 1009-1047.

Ioffe, G. (2007). Unfinished nation-building in Belarus and the 2006 presidential election. Eurasian Geography and Economics, 48(1), 37-58.

Kazharski, A. (2021). Belarus' new political nation? 2020 anti-authoritarian protests as identity building. New Perspectives, 29(1), 69-79.

Klein, G. R. \& Regan, P. M. (2018). Dynamics of political protests. International Organization, 72(2), 485521.

Kłysiński, K. (2016, 22. mars). How to get out of the crisis without reforms? The Belarusian authorities confront growing economic problems. OSW Commentary 202. Hämtat 28. mars 2021 från https:// www.osw.waw.pl/en/publikacje/osw-commentary/2016-03-22/how-to-get-out-crisis-without-reformsbelarusian-authorities

Korosteleva, E. (2009). Was there a quiet revolution? Belarus after the 2006 presidential election, fournal of Communist Studies and Transition Politics, 25(2-3), 324-346. 


\section{SOFIE BEDFORD}

Kostyugova, V. (2020). Democratic organizations: capacity building. I A. Pankovski \& V. Kostyugova (red.), Belarusian yearbook 2020: A survey and analysis of developments in the Republic of Belarus in 2019. Hämtat 28. mars 2021 från https://nmnby.eu/yearbook/2020/en/page13.html.

Kotljarchuk, A. (2020, 14. september). The flag revolution: Understanding the political symbols of Belarus. Baltic Worlds. Hämtat 28. mars 2021 från http://balticworlds.com/the-flag-revolution-understanding-thepolitical-symbols-of-belarus/

Krawatzek, F. (2019). Youth in Belarus: Outlook on life and political attitudes. ZOiS Report 5. Hämtat 28. mars 2021 från https://www.zois-berlin.de/fileadmin//Dateien/ZOiS_Reports/ZOiS_Report_5_2019.pdf

Krawatzek, F. \& Sasse, G. (2020, 4. februari). Belarus protests: Why people have been taking to the streets new data. The Conversation. Hämtat 8. februari 2021 från https://theconversation.com/belarus-protestswhy-people-have-been-taking-to-the-streets-new-data-154494

Lindberg, S. I. \& Teorell, J. (2013). Varieties of democracy (v-dem): Om att mäta demokrati och diktatur. Statsvetenskaplig tidskrift, 115(4), 273-292.

Liubakova, H. [@HannaLiubakova] (2020, 7. oktober). Every neighbourhood in \#Minsk has its own separate flag [Images attached][Tweet]. Twitter. https://twitter.com/HannaLiubakova/status/131381264455459 $2257 ? \mathrm{~s}=20$

Luxmore, M. (2020, 24. augusti). After Belarusian journalists quit state TV, Russians fill the void. Radio Free Europe/Radio Liberty. Hämtat 9. oktober 2020 från https://www.rferl.org/a/after-belarusian-journalistsquit-state-tv-russians-fill-the-void/30800576.html

Marples, D. R. (2006). Color revolutions: The Belarus case. Communist and Post-Communist Studies, 39(3), 351-364.

Marples, D. R. (2009). Outpost of tyranny? The failure of democratization in Belarus. Democratization, 16(4), $756-776$.

McAllister, I. \&White, S. (2016). Lukashenka and his voters. East European Politics E Societies, 30(2), 360-380.

Minchenia, A. 2020. Belarusian professional protesters in the structure of democracy promotion: Enacting politics, reinforcing divisions. Conflict and Society, 6(1), 218-235.

Moshes, A. \& Nizhnikau, R. (2017). Belarus's disequilibrium: Mounting challenges and reluctance to change. FIIA Briefing Paper 223. Hämtat 28. mars 2021 från https:/www.fiia.fi/wp-content/uploads/2017/10/ bp223_belarus_s_disequilibrium.pdf

Moshes, A. \& Nizhnikau, R. (2019). The Belarusian paradox: A country of today versus a president of the past. FIIA Briefing Paper 256. Hämtat 28. mars 2021 från https://www.fiia.fi/wp-content/uploads/2019/06/ bp265_belarusian_paradox.pdf.

Naumov, V. (2014). Social activism in post-communist countries and new media: The case of the tent camp protest action in Minsk, 2006. Polish Sociological Review, 187, 291-315.

Navumau, V. (2016). The Belarusian Maidan in 2006: A new social movement approach to the tent camp protest in Minsk. Peter Lang.

Newsflash. (2020, 25 mars). Belarus Dictator Says Vodka Shots, Saunas Combat COVID. [video]. YouTube. https://www.youtube.com/watch?v=sqH41yL64m8

O'Loughlin, J., Toal, G. \& Bakke, K. (2020, 17. september). Is Belarus in the midst of a generational upheaval? Global Voices. Hämtat 28. mars 2021 från https:/globalvoices.org/2020/09/17/is-belarus-in-the-midst-ofa-generational-upheaval/

Onuch, O. (2020, 16. december). Belarus rises: Four months and counting. ZOiS Spotlight 46/2020. Hämtat 28. mars 2021 från https://en.zois-berlin.de/publications/zois-spotlight-2020/belarus-rises-four-monthsand-counting/

Padhol, U. \& Marples, D. (2011). The 2010 presidential election in Belarus. Problems of Post-Communism, 58(1): 3-16.

Poleschuk, S. (2015). New intellectuals go public: 'Communication explosion' in authoritarian Minsk. [Doctoral dissertation]. Central European University CEU Electronic Theses and Dissertations (ETD). https:// sierra.ceu.edu/record=b1179495

Rainsford, S. (2020, 15. september). Kremlin looks to keep protest-torn Belarus in Moscow's orbit. BBC News. Hämtat 9. oktober från https://www.bbc.com/news/world-europe-54155882

Rudkouski, P. (2017). Soft Belarusianisation: the ideology of Belarus in the era of the Russian-Ukrainian conflict. OSW Commentary 253. Hämtat 28. mars 2021 från https:/www.osw.waw.pl/sites/default/files/ commentary_253-tv.pdf

Rudling, P. (2008). 'For a heroic Belarus!': The great patriotic war as identity marker in the Lukashenka and Soviet Belarusian discourses. Sprawy Narodowościowe, 32: 43-62. 
Rudling, P. (2017). 'Unhappy is the person who has no motherland': National ideology and history writing in Lukashenka's Belarus. I J. Fedor, M. Kangaspuro, J. Lassila \& T. Zhurzhenko (red.), War and memory in Russia, Ukraine and Belarus (s. 71-105). Palgrave Macmillan.

Rudnik, L. (2020, 1. september). Explainer: how do we know that the Belarusian election was rigged and who won the race? The Center for New Ideas. Hämtat 20. september 2020 från https://newbelarus.vision/ explainer-elections/

Ruptly. (2020, 30. mars). 'It's better to die standing than to live on your knees' - Lukashenko plays hockey [video]. YouTube. https://www.youtube.com/watch?v=BahmPnzBkr4

Schedler, A. (2006). The logic of electoral authoritarianism. I A. Schedler (red.), Electoral authoritarianism: the dynamics of unfree competition (1-23). Lynne Rienner.

Schedler, A. (2013). The politics of uncertainty: Sustaining and subverting electoral authoritarianism. Oxford University Press.

Scollon, M. (2020, 17. augusti). Lukashenka's pleas to factory workers met with jeers, not cheers. Radio Free Europe/Radio Liberty. Hämtat 17. september 2020 från https:/www.rferl.org/a/lukashenka-s-pleas-tofactory-workers-met-with-jeers-not-cheers/30788630.html.

Shkliarov, V. (2020, 4. juni). Belarus is having an anti-'cockroach' revolution. Foreign Policy. Hämtat 17. september 2020 från https://foreignpolicy.com/2020/06/04/belarus-protest-vote-lukashenko-stop-cockroach/

Sjimanovitj, G. (2017). Bednost'i sotsial'no ujazvimyje gruppy naselenija v Belarusi:posledstvija retsessii 2015-2016 gg. Issledovatel'skij tsentr IPM. Hämtat 28. mars 2021 från http://kef.research.by/webroot/delivery/files/ poverty2017.pdf

Treisman, D. (2017). Democracy by mistake. NBER Working Paper 23944. Hämtat 28. mars 2021 från http:// www.nber.org/papers/w23944

Vaisman, N. [@ nn.vsman]. (2020, 8. augusti). Ia belaruska. [Video]. Instagram. https://www.instagram.com/p/ CDn1ixSniWy/

Voice of Belarus. (2020, 20. augusti). Golos platform presents the final report on the presidential election. Hämtat 28. mars 2021 från https://www.voiceofbelarus.com/golos-final-election-report/

Wilson, A. (2018). Softly, softly Belarus. New Eastern Europe, 33(5), 7-13. 